\title{
The Competitiveness of Global Port-Cities:
}

\section{The case of Antofagasta - Chile}
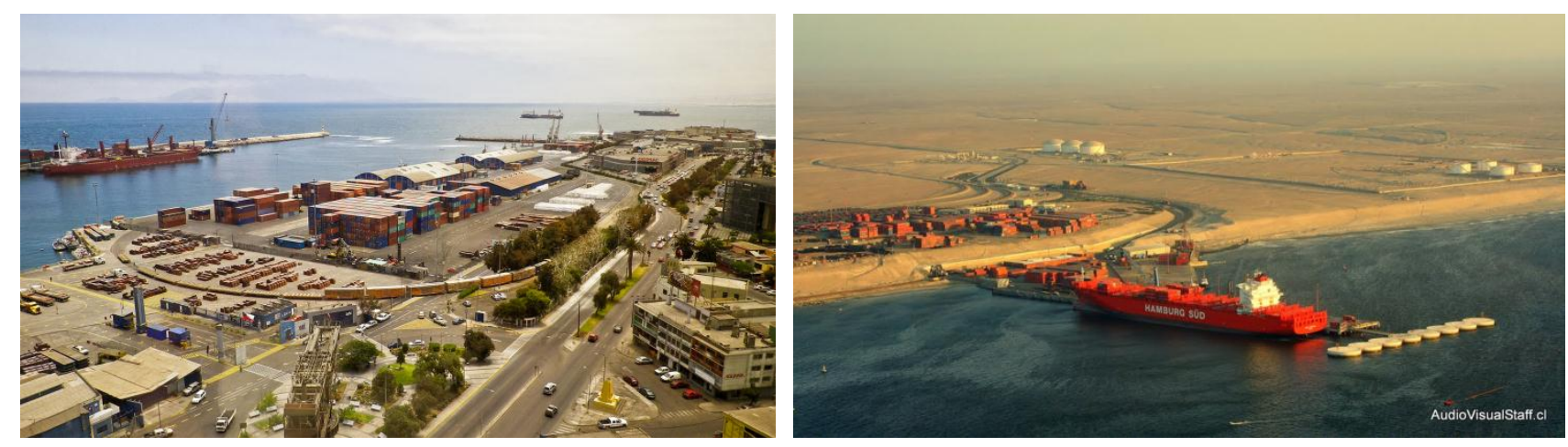

Please cite this document in the following way:

Merk, O. (2013), "The Competitiveness of Global PortCities: the case of Antofagasta - Chile", OECD Regional Development Working Papers, 2013/15, OECD Publishing, http://dx.doi.org/10.1787/5k4067cb267k-en

\section{OECD Regional Development Working Papers, 2013/15}

Olaf Merk

Classification JEL:

R41, R11, R12, R15, L91, D57 


\section{OECD REGIONAL DEVELOPMENT WORKING PAPERS}

This series is designed to make selected OECD studies on regional development issues available to a wider readership. Authorship is usually collective, but principal authors are named. The papers are generally available in their original language, either English or French, with a summary in the other if provided.

This work is published on the sole responsibility of the author(s). The opinions expressed and arguments employed herein do not necessarily reflect the official views of the OECD or of the governments of its member countries.

Comment on the series is welcome, and should be sent to gov.contact@oecd.org or the Public Governance and Territorial Development Directorate, 2, rue André Pascal, 75775 PARIS CEDEX 16, France.

OECD Regional Development Working Papers are published on www.oecd.org/gov/regional/workingpapers

Applications for permission to reproduce or translate all or part of this material should be made to: OECD Publishing, rights@oecd.org or by fax +33145249930.

(C) OECD 2013

Photo credits (from left to right): (C) Creo Antofagasta, (C) Christian Rojas Romero via www.audioVisualStaff.cl 


\begin{abstract}
This working paper offers an evaluation of the performance of ports of Antofagasta, an analysis of the impact of the ports on their territory and an assessment of policies in this field. It examines port performance over the last decades and identifies the principal factors that have contributed to it. The effect of the port on economic and environmental questions is studied and quantified where possible. The major policies governing the ports are assessed, along with policies governing transport and economic development, the environment and spatial planning. Based on the report's findings, recommendations are proposed with a view to improving port performance and increasing the positive effects of the ports of Antofagasta.
\end{abstract}

JEL classification: R41, R11, R12, R15, L91, D57

Keywords: ports, regional development, regional growth, urban growth, inter-regional trade, transportation 


\section{FOREWORD}

This study is the seventh in a series of case studies within the OECD Port-Cities Programme, directed by Olaf Merk (OECD), which attempts to identify the impact of ports on their territories and possible policies to increase the positive impacts of ports on their territories.

This working paper is part of a series of OECD Working Papers on Regional Development published by the OECD Public Governance and Territorial Development Directorate. The study on the case study was directed and written by Olaf Merk (Administrator OECD Port-Cities Programme). César Ducruet (CNRS - Université de Paris I Panthéon-Sorbonne) and Lucie Billaud (Sciences Po, Paris) also provided contributions to the study. Within the framework of this study, interviews with a series of actors and stakeholders have been conducted. The authors are grateful for the valuable support by CREO Antofagasta. The content of this working paper is also integrated in the OECD Territorial Review of Antofagasta, Chile.

The paper can be downloaded on the OECD website: www.oecd.org/regional/portcities

Further enquiries about this work in this area should be addressed to:

Olaf Merk (olaf.merk@oecd.org) of the OECD Public Governance and Territorial Development Directorate. 


\section{TABLE OF CONTENTS}

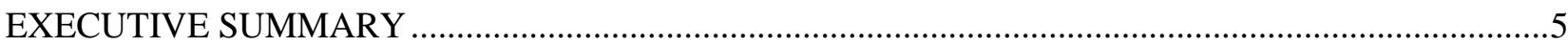

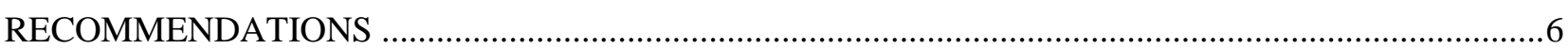

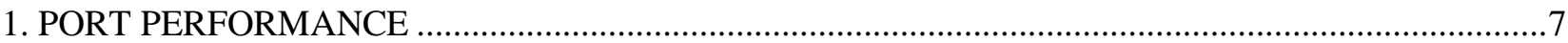

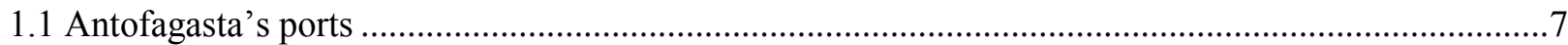

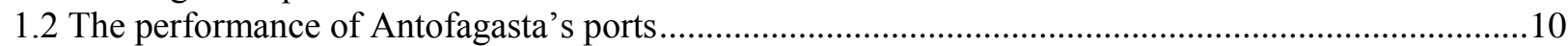

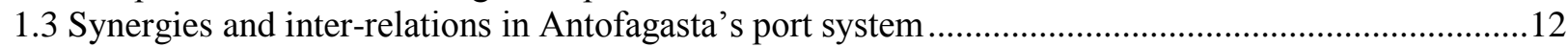

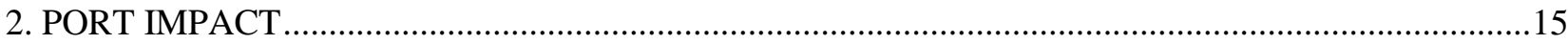

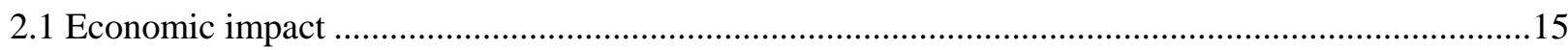

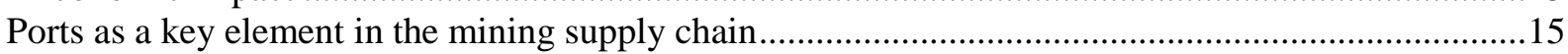

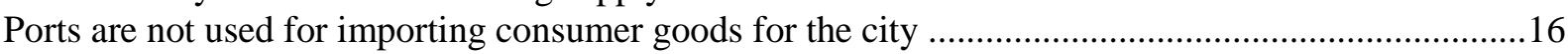

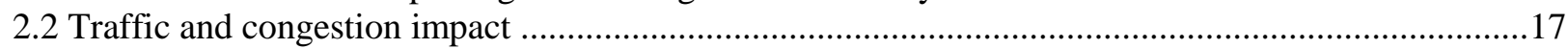

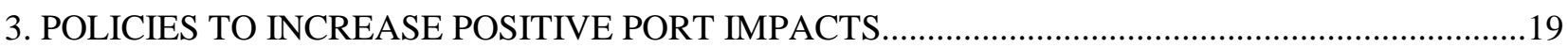

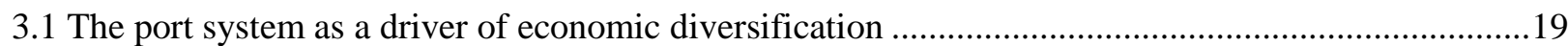

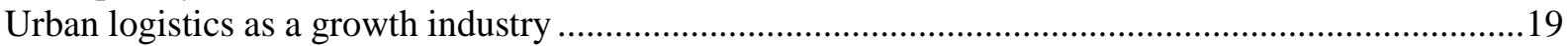

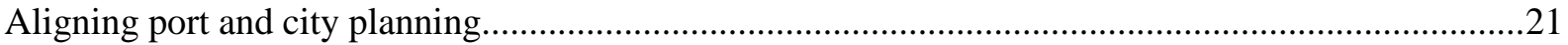

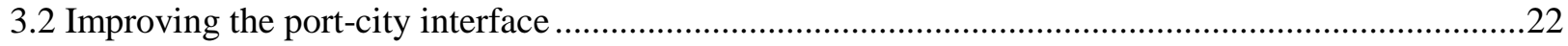

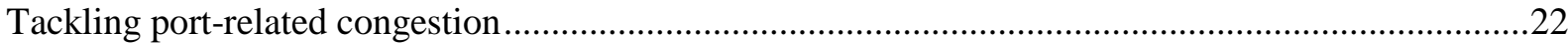

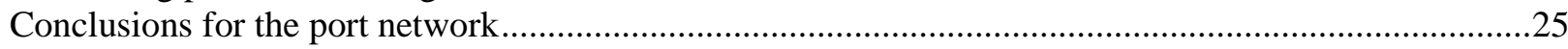

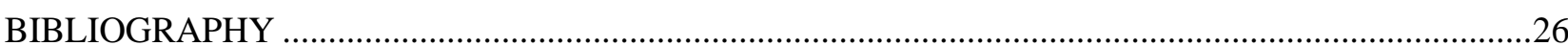

\section{Figures}

Figure 1. The 30 largest ports in Chile

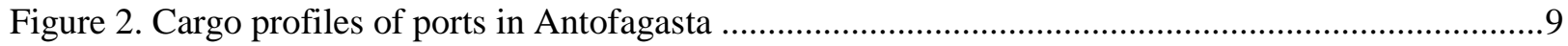

Figure 3. Cargo profiles of state-owned ports in Chile (2011) ............................................................10

Figure 4. Growth of port volumes for Antofagasta (2002-2011) ...................................................11

Figure 5. Maritime forelands of the port of Antofagasta (2004) .........................................................13

Figure 6. Maritime forelands of the port of Antofagasta (2011) ..........................................................14

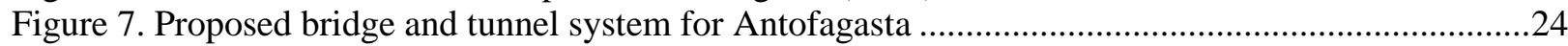




\section{EXECUTIVE SUMMARY}

There are four different ports located in and around Antofagasta, each with its own institutional status: the port of Antofagasta (publicly owned), the port of Coloso (privately owned), the port of Mejillones (privately owned) and the port of Angamos (privately owned). Together, these ports handled 11.45 million tonnes of cargo in 2011, constituting the largest port complex in Chile, with $18 \%$ of the country's total port volumes. The ports in Antofagasta all sustain the region's mining industry and its output, and each has distinct specialisations and cargo profiles. This system of different inter-related ports has also increased the resilience of the mining supply chains. For example, the ports of Antofagasta and Mejillones/Angamos, both of which serve the mining sector, are located in two different bays, subject to different currents, and cannot both be hit by a single tsunami. Their overlapping roles minimise the risk to the mining sector: if one port was put out of operation, cargo could be shifted to the other port.

The main ports in Antofagasta have different maritime connections with other international ports, based on the export markets of the mining companies using the port. The maritime connections of container vessels calling at the Antofagasta ports suggest opportunities for widening port use. For example, Antofagasta's ports are not used for importing consumer goods, although they are equipped to handle them. Both the port of Antofagasta and the port of Angamos handle container ships and general cargo ships and have the relevant equipment, but their container-related activities are dissimilar, as they only export containerised goods. Both ports need containers to export copper cathodes. As they do not import consumer goods, which would generally be transported in containers, they are obliged to import empty containers. Consumer goods destined for Antofagasta are imported via the ports in central Chile, such as Valparaíso and San Antonio, and are then transported by truck to Antofagasta. This is due to the different priorities of Antofagasta's ports and a national Cabotage Law that does not stimulate short sea shipping.

One result of the exclusive port focus on mining is an underdeveloped urban logistics sector: all logistics activity is connected to the mining sector and only a few people work in distribution centres, packing, logistics service providers, supply chain management and other jobs traditionally associated with urban logistics. A more diverse urban economy, which could include a full-fledged urban logistics sector, could make Antofagasta more resilient to shocks in the copper market.

Diversification for the ports would be a way to balance and expand port functions, stimulate the economic diversification of the city and facilitate the emergence of an urban logistics industry. Port workers and value added would be less dependent on the business cycles of the copper sector. The additional cargo could arguably bring more port-related jobs as well. In addition, it could result in a better balance between exports and imports. New corridor developments provide opportunities for diversification among Antofagasta's ports, in particular for exports to Asia from Argentina, Paraguay and other Latin American countries. As such, the ports of Antofagasta could play a role in cargo flows between the east coast of Latin America and Asia via the Pacific Ocean. In logistics parks and distribution centres, containers could be unloaded and transferred to small trucks for shipping to their final destination. Finally, an urban logistics industry would likely need a variety of services related to transport and light manufacturing, including packing and assembly, which could help further diversify the economy. Close co-operation between port, government and economic actors would be needed to stimulate port diversification that could translate into urban economic diversification. This would require a common vision by economic actors on the economic development of the city, the region, the different ports and how they could service Antofagasta, as well as how the city and the region could facilitate port development and diversification. 


\section{RECOMMENDATIONS}

- Stimulate the diversification of the ports of Antofagasta by using them to import food and consumer goods for the city's residents. This would require a shift in the focus of the various ports and liberalisation of the Chilean Cabotage Law to allow foreign-flagged vessels to engage in national short sea shipping.

- Use port diversification as a means to develop an urban logistics sector, building on current plans to develop a logistics centre just outside the city of Antofagasta. The port should be considered an urban asset. A closer link between port strategies and urban strategies would be warranted, which would require institutionalised co-operation between ports, governments and economic actors.

- Optimalise the layout and land use of the port of Antofagasta by developing the current public terminal through a concession to a private operator and moving the current storage functions to a logistics centre.

- Develop traffic management systems that would integrate freight crossing the city. Critically assess proposed infrastructure investments to solve port-related congestion, as their costs would probably outweigh the benefits 


\section{PORT PERFORMANCE}

How competitive are the ports of Antofagasta; what is their performance and what are the synergies and inter-relations between the ports? These are the questions that will be tackled in this chapter. The role of the four ports in Antofagasta will be assessed and analysed: despite their differences, they all serve the mining industry. However, the ports have different profiles, different performance trajectories and perspectives, as will be illustrated below. Despite their differences in development paths and institutional features, the ports of Antofagasta present an inter-related port system.

\subsection{Antofagasta's ports}

Antofagasta is Chile's sixth largest city in terms of population, and while it makes up $2.1 \%$ of the national population, it contributes $5.8 \%$ to the country's total GDP, playing a critical role in the Chilean economy. It is the capital of the region of Antofagasta, hosting two-thirds of its population and thus dominating a significant part of the region's economic activity. Half of Chile's total mining activity comes from copper extraction in the region. As copper represents more than half of total Chilean exports, the importance of Antofagasta in foreign trade is evident. The city of Antofagasta is bordered on one side by the Pacific Ocean and on the other by the Chilean Coastal Range, with mines located approximately 200 kilometres inland.

There are four different ports located in and around Antofagasta. Two of these are in the city of Antofagasta: the port of Antofagasta in the city centre and the port of Coloso at the southern edge of the city. The other two ports are in Mejillones, a town of 10000 inhabitants 60 kilometres to the north of Antofagasta (Figure 1): the port of Mejillones and the port of Angamos, are located right next to each other. Each of these ports has a different institutional status and context: the port of Coloso is a private port owned by Minera Escondida, the port of Angamos is a private port owned by a consortium of the Ultramar logistics company and the construction company Belfi, but which is open to other clients, as is the port of Mejillones, which has various terminals operated by different private operators. Unlike these ports, the port of Antofagasta is a publicly owned port, but the majority of traffic is handled by a private concessionaire (ATI). To complicate matters further, the port of Angamos is part of what is called the Mejillones Port Complex, an organisation initiated by the CODELCO mining company, covering an area where future port activity (not exclusively mining-related) is planned, sometimes also referred to as the "Mejillones MegaPort".

Taken together, these ports handled 11.45 million tonnes of cargo in 2011, which, in total, makes the region of Antofagasta the largest port complex in Chile, representing 18\% of total Chilean port volumes. The largest Chilean port, the port of San Antonio, handled 11.39 million tonnes of cargo in 2011. The largest port of Antofagasta, in terms of cargo volumes handled, is Mejillones (4.8 million tonnes in 2011), followed by Antofagasta (3.0 million), Angamos ( 2.0 million) and Coloso (1.6 million). Neither of these ports is the largest port in the three categories of ports that exist in Chile, namely state-owned ports, privately owned ports open to public service, and privately owned ports only open to use by the private owner. Antofagasta is the fifth-largest public port, Mejillones is the second-largest and Angamos the eighth-largest private port open to public service, whereas Coloso is the fifth-largest private port (Figure 2). The share of containers handled in Antofagasta is relatively limited: only $7 \%$ of total container volume of Chilean ports, with both Angamos (130 000 twenty foot equivalents [TEUs] in 2011) and Antofagasta (100 000 TEUs), far behind the largest Chilean container port of Valparaíso (970 000 TEUs in 2011). 
Figure 1. The geographical location of Antofagasta and Mejillones

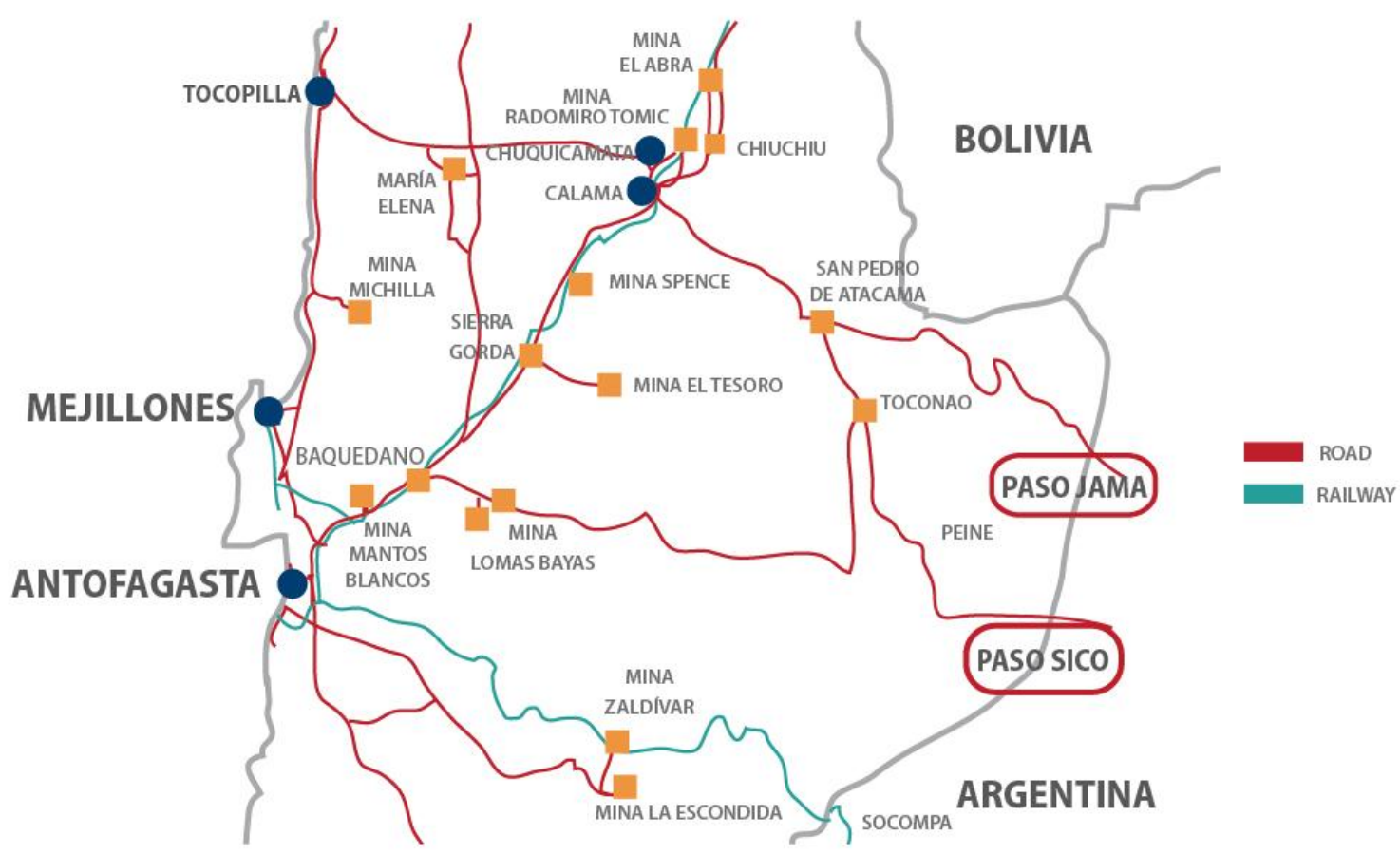

Source: Commercial presentation Puerto Mejillones

Figure 2. The $\mathbf{3 0}$ largest ports in Chile

Port throughput in millions of metric tonnes (2011)

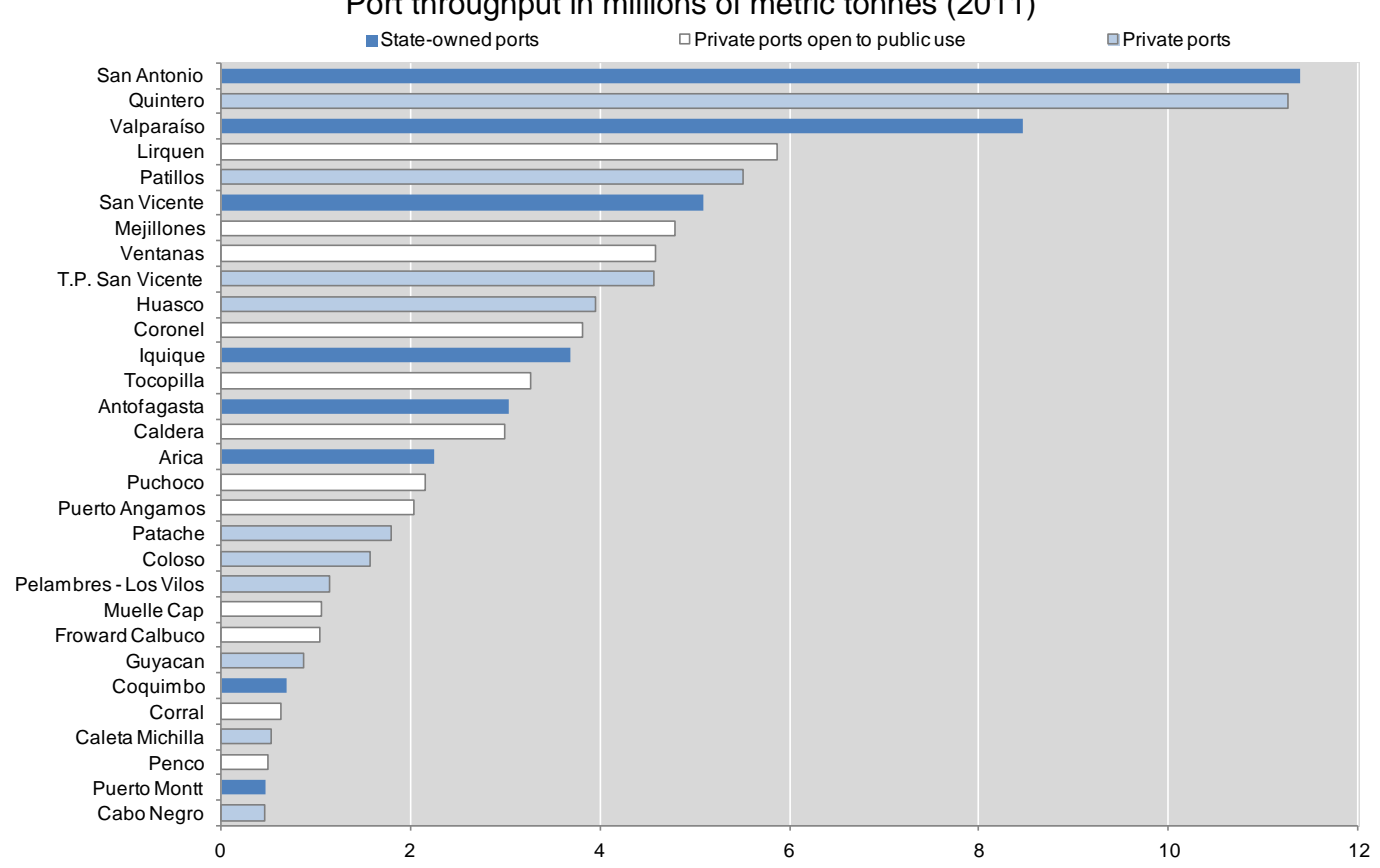

Source: based on data from Cámara Maritima y Portuaria de Chile AG. 
The ports in Antofagasta are all used to sustain the region's mining industry. The main mining products exported from Antofagasta are copper concentrates, copper cathodes (copper plates) and other mineral products that can be considered by-products of the copper mines. Imported products used for copper production are chemicals such as sulphuric acid. The four ports all have distinct specialisations in these products, leading to the large differences in their cargo profiles (Figure 3). The port of Coloso handles only copper concentrate, a dry bulk product that has the outward appearance of black powder, transported directly from the Escondida mines to the port by pipeline, where the water is extracted and the concentrate is loaded on dry bulk ships. The port of Mejillones handles mostly liquid bulk, which is unloaded from tankers by pipeline into the port and then transported by train or truck into some of the mines. Both the ports of Antofagasta and Angamos are used to export copper concentrate and copper cathodes. The copper concentrate is transported by train to both ports, where it is loaded into dry bulk ships. The copper cathodes come by truck or train to the port area, where they are put into containers, which are then loaded on container ships. As the ports do not import containerised goods, they import empty containers needed for exporting the cathodes. In addition, the port of Angamos handles breakbulk cargo and project cargo related to the mining sector, such as shovels and other equipment.

Figure 3. Cargo profiles of ports in Antofagasta

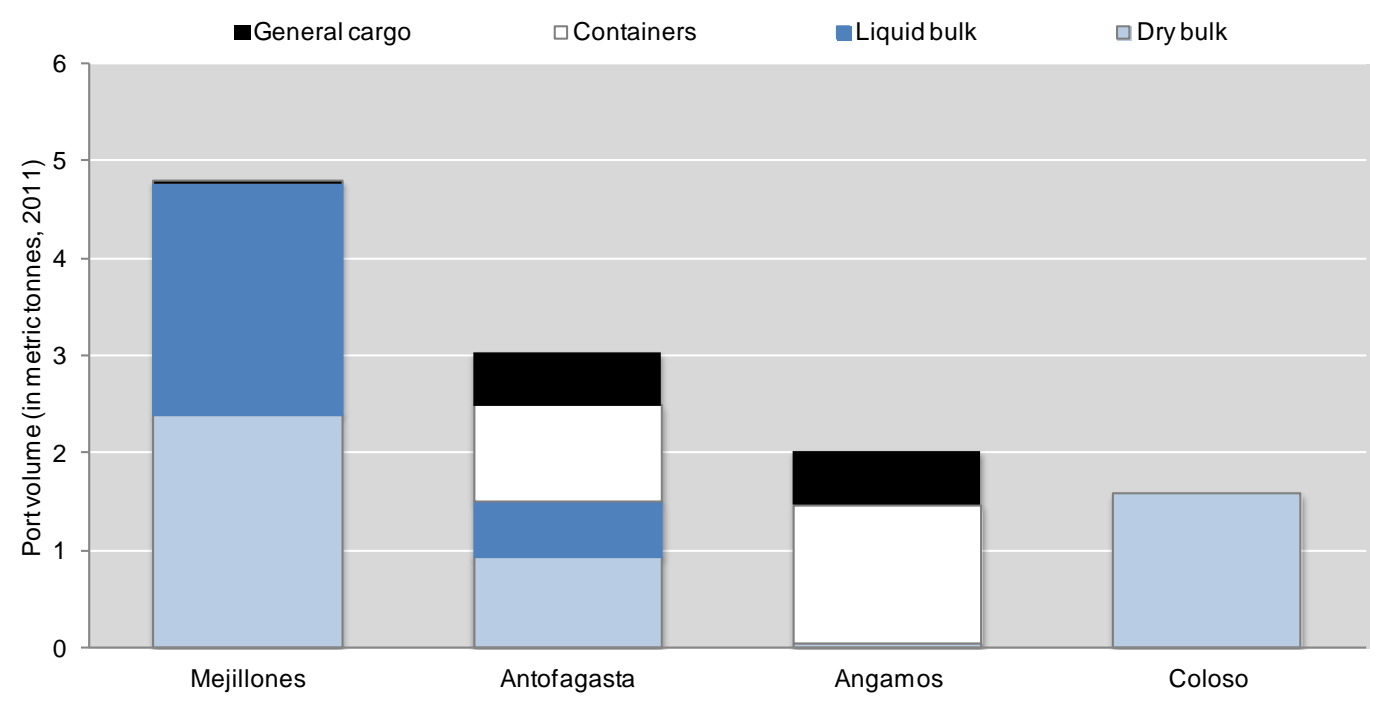

Source: based on data from Cámara Maritima y Portuaria de Chile AG.

Exclusively serving the mining sector, the highly specialised ports of the Antofagasta region have a fundamentally different role from the main ports in central Chile, and most other ports worldwide. Most ports have multiple functions and a large variety of clients; in addition to their function for industrial users, they play a key role for city-regions by importing and exporting consumer goods and food. This function could be expressed by the containerisation rate and share of refrigerated goods in the total cargo handled in the port. ${ }^{1}$ Based on these indicators, it can be concluded that the main state-owned ports in central Chile have a different profile from Antofagasta and other specialised mining-related ports: Valparaíso, San Antonio and San Vicente have much higher shares of containerisation and refrigerated cargo, ranging from

1. The containerisation rate is admittedly an imperfect proxy for consumer goods in total cargo, as raw resources and intermediate goods for industrial use are also increasingly transported by containers. The case of Antofagasta illustrates this well, where all of the container transport is, in fact, transport of copper cathodes. Nevertheless, there is a limit to industrial products and inputs that can be transported by container. 
$60-90 \%$. This rate is approximately $30 \%$ in Antofagasta, whose profile is similar profile to that of Iquique, another mining-related port in northern Chile (Figure 4). The port of Arica, although it is located in a northern mining region, has a profile similar to those of the main central Chilean ports, due to its function as maritime gateway for Bolivia.

Figure 4. Cargo profiles of state-owned ports in Chile (2011)

Shares of containerised and refrigerated cargo (in \%)

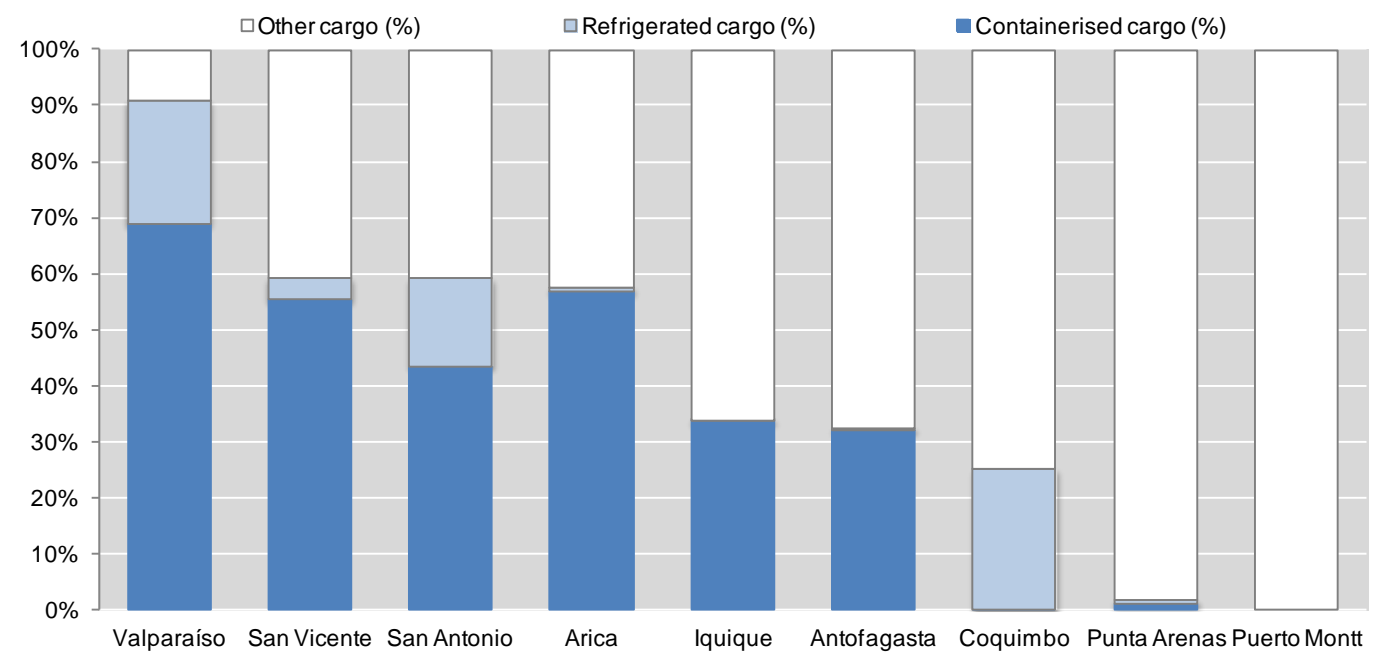

Source: based on data from Cámara Maritima y Portuaria de Chile AG.

\subsection{The performance of Antofagasta's ports}

The ports in the region of Antofagasta have grown at sustained high rates, doubling throughput over the last decade. Port volumes increased from 6.4 million tonnes in 2002 to 11.4 million tonnes in 2011, with only a brief and relatively small backdrop of volume in 2009 related to the global financial and economic crisis. Port growth is driven by the ports of Mejillones and Puerto Angamos, whose throughputs more than tripled over this period, whereas the volumes of the ports of Antofagasta and Coloso remained more or less stable over the 2002-2011 period (Figure 5). The reason why Angamos did relatively better than Antofagasta in 2011, thus gaining market share relative to that port, is partly related to labour conflicts in the port of Antofagasta: during this period of port strikes, cargo shifted to the port of Angamos, which explains its increased market share in 2011. 
Figure 5. Growth of port volumes for Antofagasta (2002-2011)

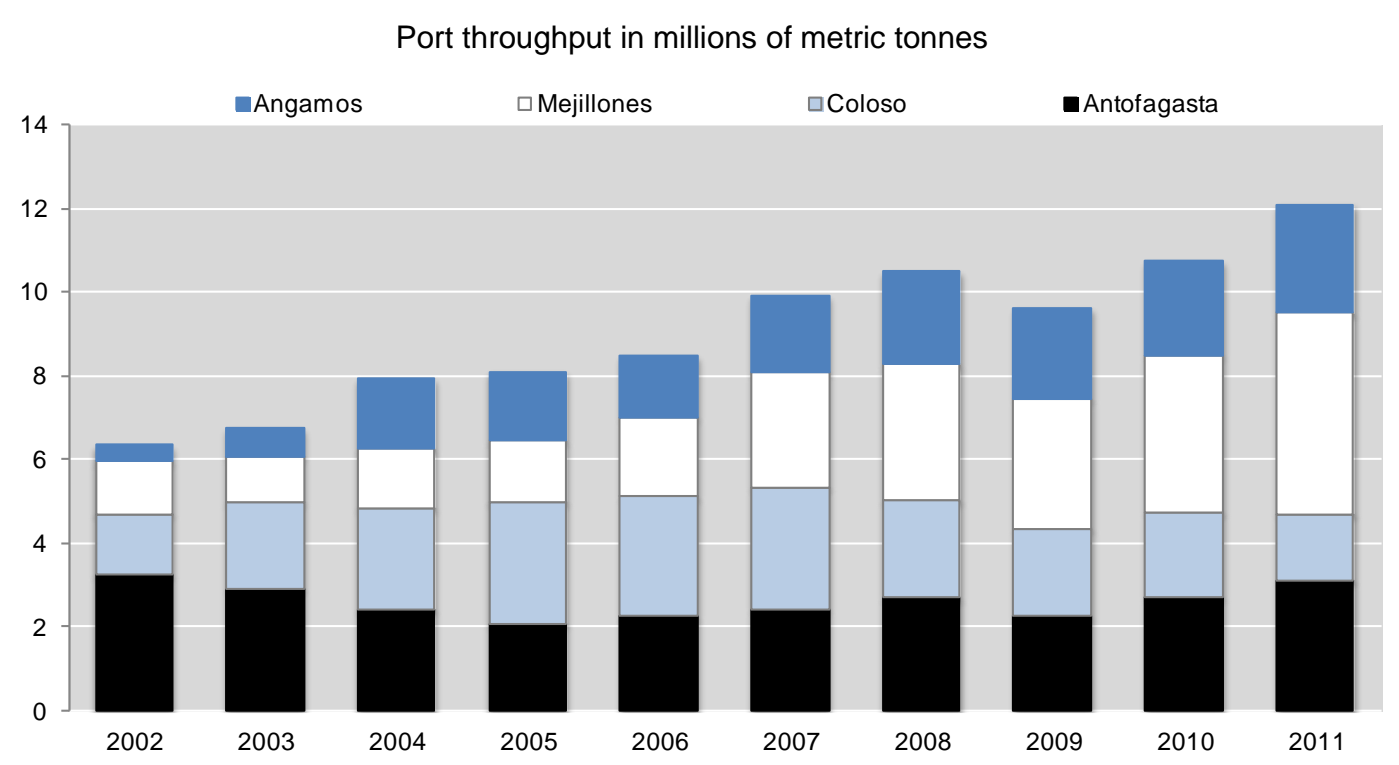

Source: based on data from Cámara Marítima y Portuaria de Chile AG, Puerto Angamos, Puerto de Antofagasta, Economic Commission for Latin America and the Caribbean.

Due to the exclusive use of the ports by the mining sector in the region and the captive market, port growth rates cannot be considered the most pertinent performance indicator of Antofagasta's ports. The growth rates of the Antofagasta ports have generally followed mining output in the region, so their growth rates are a function of mining productivity rather than their capacity to capture cargo. Moreover, although the ports compete to some extent with each other, in particular Antofagasta and Angamos, their mining hinterland can be considered captive, that is, not subject to competition from ports in other regions, since the transport costs from the mines to more distant ports would be prohibitive. The rapid growth of the ports of Mejillones does not necessarily indicate optimal performance. An important performance indicator in this respect would be the efficiency of the ports within the total mining supply chain. This would require an assessment of scores on vessel turnaround time in port, port utilisation rates (port capacity per output), waiting time before entering the port and efficiency of yard operations. These indicators are not publicly available, making it difficult to provide a comparative and quantitative assessment of the efficiency of Antofagasta's ports. However, a more qualitative assessment of port efficiency is possible and is presented below.

The efficiency of the port of Antofagasta is constrained by underdevelopment of the publicly operated berths, suboptimal port layout and lack of space. The port of Antofagasta has two terminals. One terminal, consisting of Berths 4-7, is operated by the private terminal operator Antofagasta Terminal Internacional (ATI), and Terminal 1 is operated by the port authority itself, the Empresa Portuaria Antofagasta (EPA). In order to stimulate privatisation of port operations to private terminal operators via concessions, national port legislation on state-owned ports prohibits the public port authority from investing in port superstructure (such as cranes). Although this provision is intended to avoid public sector investments in terminal operation, which is in essence a private economic activity, in practice, it has led to a situation in which many Chilean ports have terminals that they cannot productively use unless these are privatised. As a result, the EPA terminal only handles a marginal share (less than 5\%) of the total throughput of the port of Antofagasta. In practice, most of the terminal area is used for storage and container stuffing related to traffic at the ATI terminal. Paradoxically, the EPA terminal, which receives very few ships, has a layout more suitable for receiving large container ships than the ATI terminal, as it has a much longer quay length. The Port Master Plan of the port of Antofagasta aims to solve this situation by proposing to 
concession out Terminal 1, which would allow for private investment in container cranes, while at the same time including a berth that would be able to handle post-Panamax ships. This proposal is not without difficulties, as it would undermine the position of the ATI terminal and probably lead to re-negotiation of the current concession agreement. It would also require relocating the storage and container stuffing functions in place at the EPA terminal to a location outside the city, due to space constraints. If welldesigned, this could provide an efficient alternative for ATI and a more effective use of the quays of the port.

\subsection{Synergies and inter-relations in Antofagasta's port system}

Antofagasta's ports have developed into an inter-related port system. For example, the Xstrata Copper smelter in La Negra receives much of its copper concentrate from Coloso, while exporting its copper anodes via the ports of Antofagasta and Angamos. Some copper mines receive sulphuric acid from Mejillones and export their copper products via the other ports. In this way, the different ports of Antofagasta form part of a network of economic relations. Within this system, each port has different specialisations and equipment. As mentioned before, the port of Coloso handles only copper concentrate; the port of Mejillones mostly handles liquid bulk such as sulphuric acid, while the ports of Antofagasta and Angamos have a relatively more diverse cargo profile, although all cargo is mining related.

Each port also has different clients and ownership relations. The port of Coloso is owned by Minera Escondida and works exclusively for it. The port of Angamos is the dedicated port for the CODELCO mining company. Although it is open to other customers, approximately $90 \%$ of the cargo handled by the port of Angamos is related to CODELCO. The ATI terminal has economic links with the industrial group Antofagasta PLC, which exploits Minera Michilla, Minera Esperanza and Minera Tesoro, located north of the city of Antofagasta. Part of the Antofagasta PLC group is the private rail company Ferrocarril de Antofagasta (FCAB), which has a 30\% stake in ATI and provides the rail services between the ATI terminal and the mines. As a result, the main ports in Antofagasta have different maritime connections with other world ports, determined by the export markets of the mining companies using the port. Copper concentrate is directly transported in bulk carriers to manufacturing centres and their ports, for example, to the People's Republic of China.

The maritime connections of container vessels calling at the Antofagasta ports indicate the potential opportunities of widening port use. The final destinations of the container vessels transporting the copper cathodes is relatively difficult to track, as they call in at various other Chilean ports before reaching their destination. As a result, a large share of the direct connections of the port of Antofagasta is with other Latin American ports (Figure 6). These Latin American connections indicate the extent to which the existing port service loops could be used for cargo other than mining-related cargo. Between 2004 and 2011, the links with diverse Asian ports have become more important, to such an extent that by 2011, the cargo from Antofagasta represented a considerable share of the throughput of the Japanese port of Saganoseki, home to the copper smelter of Pan Pacific Copper (Figure 7). These links could also be used for imported goods to Chile. 


\section{ANTOFAGASTA (2004)}

Traffic share at

world ports' total (\% GRT)

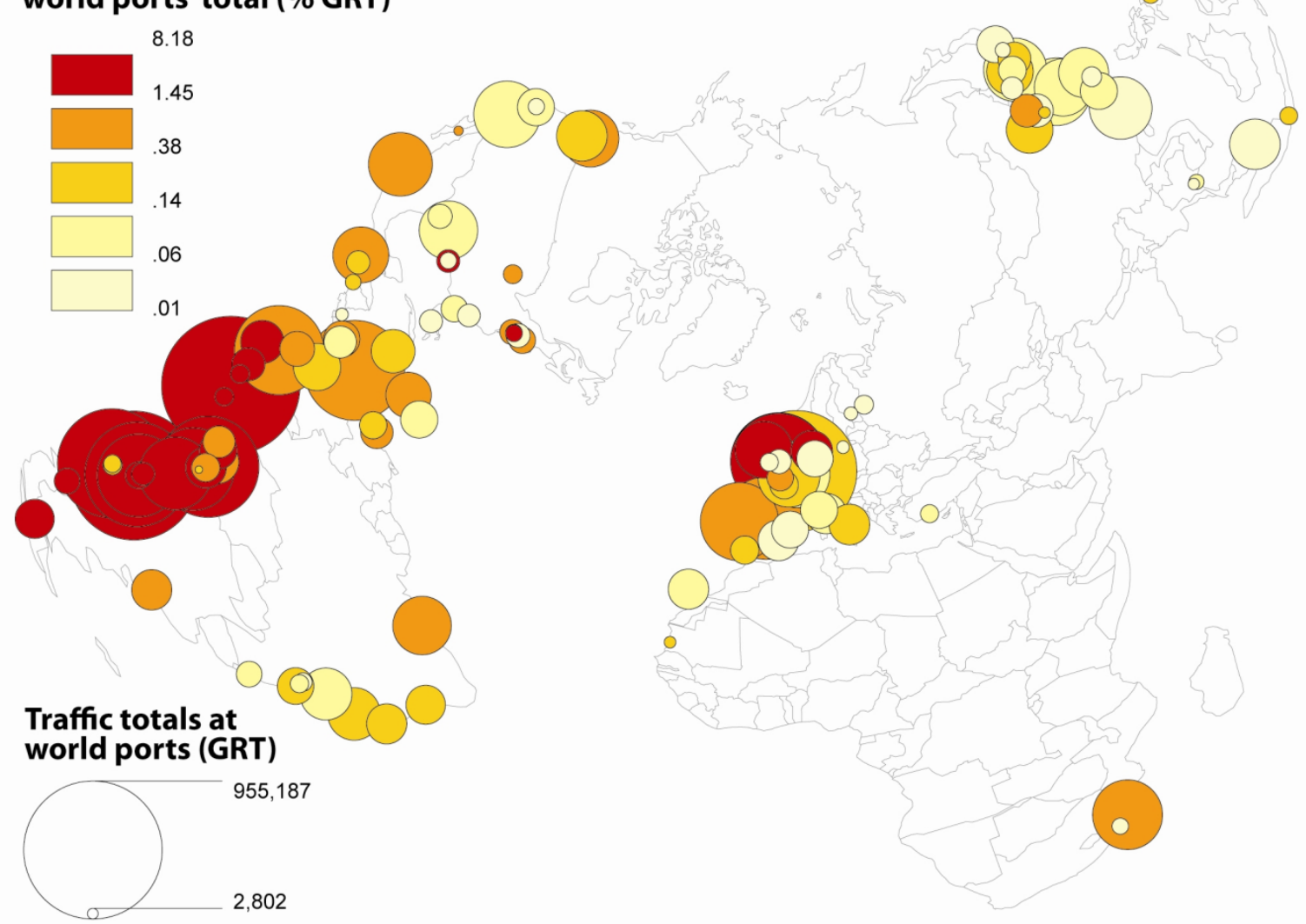

Source: based on data from Lloyd's Marine Intelligence Unit. 


\section{ANTOFAGASTA (2011)}

\section{Traffic share at \\ world ports' total (\% GRT)}

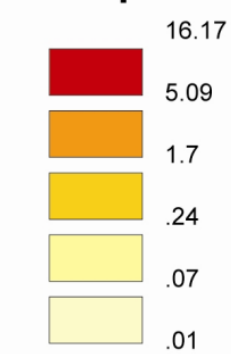

world ports (GRT)

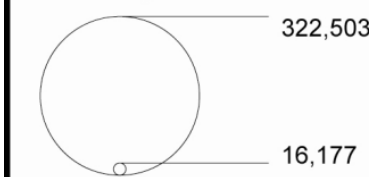

Source: based on data from Lloyd's Marine Intelligence Unit.

The system of different inter-related ports has increased the resilience of the mining supply chains. The geographical location of the ports of Antofagasta and Mejillones/Angamos is such that they cannot both be hit by a tsunami: they are located in two different bays, subject to different currents. Having both ports serving the mining sector and having overlapping roles thus spreads the risks for the mining sector: if one port is rendered inoperative, cargo could be shifted to the other port. That this is not a hypothetical situation can be illustrated by the cargo shifts from Antofagasta to Angamos during the port strikes in Antofagasta, which could be won back by Antofagasta if it outperforms Angamos. 


\section{PORT IMPACT}

What is the impact of the ports on the city-region of Antofagasta? This chapter will demonstrate that the ports are essential to the mining supply chain in Antofagasta, but that the ports are not used for importing consumer goods to the city-region. At the same time, there are certain port impacts on traffic and congestion.

\subsection{Economic impact}

\section{Ports as a key element in the mining supply chain}

Transport costs represent a substantial share of the production costs of copper exports. For instance, Antofagasta PLC indicates that $14 \%$ of its weighted average cash costs in 2011 were on shipping and tolling charges. ${ }^{2}$ Inefficient port operations in the port of Antofagasta would translate to inefficient use of its fleet of trains and trucks, larger stocks in the mining area and thus in less-beneficial financial results. Similarly, inefficient operations in the port of Coloso could lead to bottlenecks elsewhere in the Escondida supply chain, to waiting times for ships, and additional costs imposed on clients that they might try to recover from Escondida. Well-functioning ports are thus essential for Antofagasta's mining sector. In comparison with other copper producing countries, such as Canada, Australia and Indonesia, the maritime transport costs for Chilean copper as transported in container seem to be relatively low (Table 1), at least for exports to countries for which data were available in the OECD Database on Maritime Transportation Costs. For many of the multinational copper companies, the planning, technology and equipment used in Antofagasta's ports could be considered of strategic value for operations in new port sites around the world; the specialised knowledge and innovations of the niche ports in Antofagasta are to some extent transferable and exportable.

Table 1. Maritime transport costs for copper in containers (2007)

\begin{tabular}{lcccc}
\hline From/to & US & Australia & Brazil & New Zealand \\
\hline Chile & 0.0465 & 0.1382 & 0.0799 & 0.1772 \\
Canada & 0.6197 & 0.2917 & 0.0781 & 0.2284 \\
Australia & 0.2257 & & 1.2308 & 0.0610 \\
Indonesia & 0.2723 & 0.4067 & 1.0147 & 0.6112 \\
\hline
\end{tabular}

Source: OECD Maritime Transportation Costs Database

Note: Unit transport costs

The Antofagasta ports are also a considerable source of employment, in particular in Angamos. According to representatives of the various ports, approximately 500 jobs are directly related to the port of Antofagasta, around 700 to the port of Angamos, and a few dozen in the ports of Coloso and Mejillones. The reason behind such discrepancies are the types of cargo handled in the different ports, with the handling of dry bulk in the port of Coloso and of liquid bulk in Mejillones almost completely automated, whereas the handling of general and containerised cargo in Antofagasta and in particular Angamos (which is also specialised in project cargo) requires more labour. Especially in the town of Mejillones, the port cluster can be considered an important employer, even if approximately $40 \%$ of the workers in the port of Angamos commute from Antofagasta, transported in company buses to and from the port.

\footnotetext{
2. Cash costs are a measure of the cost of operational production expressed in terms of cents per pound of payable copper produced. Cash costs are stated net of by-product credits and include tolling charges for concentrates. Cash costs exclude depreciation, financial income and expenses, hedging gains and losses, exchange gains and losses and corporation tax for operations.
} 


\section{Ports are not used for importing consumer goods for the city}

The Antofagasta ports are not used for importing consumer goods, despite having the equipment to handle it. Both the port of Antofagasta and the port of Angamos handle container ships and general cargo ships and have the relevant equipment, but their container-related activities are asymmetrical, as they only export containerised goods. Both ports need containers to export the copper cathodes. As they do not import consumer goods, which would generally be transported in containers, they are obliged to import empty containers. The consumer goods for Antofagasta are imported via the ports in central Chile, such as Valparaíso and San Antonio, and are then transported by truck to Antofagasta.

This situation can be explained by the different priorities of Antofagasta's ports and a national Cabotage Law that does not encourage short sea shipping. The ports in Antofagasta are all more or less linked to the mining industry, either directly owned (Coloso) or managed by companies in which mining companies have an important stake (Angamos, ATI, Mejillones). Their focus is on the mining supply chain. A result of the ports' exclusive focus on mining is an underdeveloped urban logistics sector: all the logistics activity is connected to the mining sector, and only a few people work in distribution centres, packaging, logistics service providers, supply chain management and other jobs traditionally associated with urban logistics. A more diverse urban economy, which could include a fully-fledged urban logistics sector, could make Antofagasta more resilient to shocks in the copper market.

Chile's Cabotage Law, dating back to 1978, restricts national short sea shipping (cabotage) to ships carrying the Chilean flag, which are the only ones allowed to load cargo in one Chilean port and unload in another port. Foreign-flagged vessels can call at different Chilean ports but cannot cater to the national market (i.e. they may pick up containers in Valparaíso and Antofagasta, but cannot transport a container from Valparaíso and unload it in Antofagasta). Meanwhile, the number of Chilean-flagged vessels available for short sea shipping is limited. These restrictions are used in many countries: and sometimes more restrictive than in Chile to protect national ship owners (Table 2). They effectively prevent the emergence of domestic maritime transport as a viable mode of transport. This influences the prices for consumer goods in Antofagasta. The price of a television in Antofagasta, for example, might be reduced if it were imported at its own port rather than via the central Chilean ports, and saved on the trucking costs, considering that the maritime leg between central Chilean ports and Antofagasta would be marginal. 
Table 2. National cabotage laws and restrictions

\begin{tabular}{|c|c|c|c|}
\hline Country & Domestic Construction Provisions & Ownership Restrictions & Crewing Requirements \\
\hline Argentina & No & Yes & Yes \\
\hline Australia & No & No & Yes \\
\hline Belgium & No & No & Yes \\
\hline Brazil & Yes & Yes & Yes \\
\hline Canada & No & Minor & Yes \\
\hline Chile & No & Yes & Yes \\
\hline China & No & Yes & Yes \\
\hline Colombia & No & Yes & Yes \\
\hline Cyprus & No & No & No \\
\hline Denmark & No & Yes & Yes \\
\hline Ecuador & No & Yes & Yes \\
\hline Egypt & Minor & Yes & Yes \\
\hline Finland & No & Yes & Yes \\
\hline France & No & Minor & Yes \\
\hline Germany & No & No & Minor \\
\hline Greece & No & Yes & Yes \\
\hline Honduras & No & Yes & Yes \\
\hline India & No & Yes & Yes \\
\hline Indonesia & Yes & Yes & Yes \\
\hline Israel & No & No & No \\
\hline Italy & No & No & Minor \\
\hline Japan & No & Yes & Yes \\
\hline Kenya & No & No & No \\
\hline Malaysia & No & Yes & Yes \\
\hline Malta & No & No & Minor \\
\hline Mexico & No & Yes & Yes \\
\hline Netherlands & No & Yes & Minor \\
\hline New Zealand & No & Yes & Yes \\
\hline Nigeria & No & Yes & Yes \\
\hline Norway & No & Yes & No \\
\hline Panama & No & No & No \\
\hline Peru & Yes & Yes & Yes \\
\hline Philippines & No & Yes & Yes \\
\hline Saudi Arabia & No & Yes & No \\
\hline Singapore & No & No & No \\
\hline South Africa & No & No & No \\
\hline South Korea & No & Yes & No \\
\hline Spain & Yes & n.a. & Yes \\
\hline Sweden & No & Yes & Minor \\
\hline Taiwan & 1 & n.a. & Yes \\
\hline Thailand & No & Yes & Yes \\
\hline United Kingdom & No & No & Yes \\
\hline United States & Yes & Yes & Yes \\
\hline Uruguay & No & No & Yes \\
\hline Venezuela & No & Yes & Yes \\
\hline
\end{tabular}

Source: Marad 2001

\subsection{Traffic and congestion impact}

Antofagasta faces a certain amount of road congestion, partly due to port-related traffic. Like almost all cities, Antofagasta suffers from congestion, thanks to extensive use of private cars and limited use of public transport. This influences the urban quality of life. Truck traffic is one of the factors contributing to urban congestion in Antofagasta, but the share of truck traffic related to port activity is quite limited. According to OECD estimates generated for this review, approximately 100 trucks go to the port of Antofagasta daily, spread throughout the day. In the Chilean context, this number is relatively limited: e.g. the average number of port-related truck movements in Valparaíso is approximately 25 times higher. One of the reasons for the relatively limited port-related road congestion is that approximately $70 \%$ of the copper cathodes transported to the port arrive by train. There are truck movements related to the other ports, but these do not contribute to the congestion in the city of Antofagasta. The road links between the 
port of Mejillones/Angamos and the mines in northern Antofagasta that they mostly service do not go through the city of Antofagasta and use the B400 Bypass Route 5. Part of the copper concentrate arriving in the port of Coloso via the pipeline connection with the Escondida mine is transported by truck to copper smelters in La Negra, using the roads to the south of the city Antofagasta through the mountains.

The cargo train between the port of Antofagasta and the mines regularly crosses main roads in the city. This represents a total of 200 wagons per day in and out of the port of Antofagasta: trains of approximately 25 wagons in length, crossing the city 11 times on average within a 24-hour period, with at least 4 crossings across main urban roads within the city of Antofagasta. These train wagons mainly transport copper cathodes. The trains connected to Mejillones transport sulphuric acid from the port (these do not go through the city) and cathodes to the port, but only a limited share of these pass through the city of Antofagasta, according to the FCAB. Port-related hinterland traffic, as well as port operations and shipping, have certain environmental impacts that are not systematically measured in Antofagasta, making them difficult to quantify and put in comparative perspective. 


\section{POLICIES TO INCREASE POSITIVE PORT IMPACTS}

What are the main policies that could be applied to increase the positive impact of the ports of Antofagasta? This chapter identifies two main policy directions: first, to use the port system as a driver of economic diversification of the city-region, and second, to improve the port-city interface, mainly by tackling port-related congestion.

\subsection{The port system as a driver of economic diversification}

\section{Urban logistics as a growth industry}

An exclusive port focus on mining production is common in the world's mining regions, but several ports servicing copper mines also have wider urban functions, as they import consumer goods for their citizens. Resource-related cargo handling needs specific equipment that cannot be used for handling general cargo, such as loading arms for loading copper concentrate and pipelines for unloading oil and sulphuric acid. For this reason, the potential for diversification in the ports of Mejillones and Coloso is limited: their equipment would not allow them to import food and consumer goods, generally imported as breakbulk or in containers, needing cranes. However, both Antofagasta and Angamos have equipment that could be used for handling cargo that is not related to mining. As in the port of Vancouver, they might be able to handle both mining-related cargo and urban consumer goods.

Diversification for the ports would be a way to balance and expand port functions. This would make port workers and value-added less dependent on the business cycles of the copper sector. The additional cargo would arguably bring more port-related jobs and value-added. In addition, it could bring a better balance between exports and imports. The ports of Antofagasta and Angamos are basically only exporting ports, and as a large share of their exports goes into containers, they have to import empty containers. This could be avoided if the ports imported consumer goods destined for the region, thereby bringing in containers that could be re-used for exporting the copper cathodes. This is currently a side issue, because customers are bearing the transport costs related to importing the containers, but these costs could translate into cost savings.

New corridor developments provide tremendous opportunities for diversification at Antofagasta's ports. The planned Bi-oceanic Aconcagua Corridor would create a railway crossing in the Andes mountain range to link the towns of Luján de Cuyo, in Mendoza, Argentina, with Los Andes, in Chile, circumventing the Chilean-Argentinean border crossing at Cristo Redentor Pass in Mendoza, which can be closed for up to 60 days in winter. This could present new opportunities for port diversification in Antofagasta, in particular for exports from Argentina, Paraguay and other Latin American countries to Asia. The ports of Antofagasta could play a role in cargo flows between the east coast of Latin America, such as Brazil and Uruguay, and Asia, via the Pacific Ocean, since the current routes via the Panama Canal or Strait of Magellan are not ideal, considering the detours that they require. In addition to mineral products, for which Antofagasta's ports are already well equipped, other commodities, including agricultural and food products, could be included.

Port diversification will stimulate the economic diversification of the city and facilitate the emergence of an urban logistics industry. This could take the form of logistics parks and distribution centres, where the containers could be de-stuffed and transferred to small trucks for reaching their final destination. In many countries, this takes the form of port-centred logistics, e.g. in Savannah, Georgia, in the United States. It could lead to the emergence of an urban freight transport sector, with a specialised fleet to service the city and region of Antofagasta. The emergence of Antofagasta as a regional logistics centre could also attract freight from other parts of Latin America over road and rail that is currently shipped out through 
other Latin American ports. Finally, an urban logistics industry is likely to need a variety of services related to transport and light manufacturing, including packaging and assembly, which could help further diversify the economy.

\section{Box 1. Savannah Logistics Centre}

The Port of Savannah is the main component of the logistics hub of Savannah because of the importance of its market, oriented to transcontinental trade, and the amount of cargo transiting the port. The growth of global business and the amount of incoming and outgoing cargo at the port of Savannah highlighted the need for warehouse and distribution center in the region (Atlanta Business Chronicle, 2009). The logistics center of Savannah is specially developed with the aim to support this request. The Georgia Port Authority owns and operates the Port of Savannah while A \& B Properties and Colliers Neely Dales are the main promoters and developers of this logistics pole (A \& B Properties, 2009).

The Port of Savannah handled almost 3 million TEUs in 2011 and plans to increase its capacity to 4 million TEUs by 2015 . These growth forecasts have led to the construction of warehouses. There is a strong demand for storage of approximately 50,000 m2. The developers plan to increase the operating site by monopolizing land in Jasper County, South Carolina. The acquisition of new land will allow the logistics centre to double the size of its land (Brown, 2009).

The logistics center is part of the Savannah extensive rail network of Northfolk Southern Railway, which offers comparative advantages of transportation. Savannah facilitates the transfer of containers from rail to vessels with a direct connection to the port. The essentially bimodal network can serve the U.S. East Coast, including the ports of New York/New Jersey, Philadelphia and Baltimore (Lower Savannah Council of Governments, 2002). Savannah offers especially services related to storage and distribution in the region (Southeast Real Estate Business, 2006).

An important condition for more short sea shipping to Antofagasta is a reform of the Chilean Cabotage Law. This is currently under way and should be carried through. In April 2012, the Chilean government, through the Ministry of Economy and the Ministry of Transport, introduced legislation to change this law. It aims to permit foreign merchant ships upward of 2000 deadweight tonnes (dwt) to offer cabotage services. The proposal also includes eliminating additional barriers deterring foreign ships from cabotage, such as an additional tax of $20 \%$ of the value of the contract. Nevertheless, the proposal keeps the "national reserve" (reserva nacional) for small ships serving remote areas of the country. The government expects a $10 \%$ decrease on the price of cabotage, rendering this activity more competitive with other modes of transport, and providing new impetus for diversified port activity (Revista del Management Logistico, 2012).

Other changes in the business model and infrastructure in the ports of Antofagasta would be needed. To play a role in the food supply chain, the ports of Antofagasta and Angamos would need refrigerated warehouses and plugs for the reefer containers used for refrigerated transport. Container cranes would be required for containerised cargo. Most importantly, both port authorities would have to more actively attract cargo, both by investing in maritime connectivity to encourage large carriers to call in Antofagasta and by linking businesses in the Latin American hinterland to the Antofagasta ports.

The additional port traffic related to diversification driven by reform of the Cabotage Law and the establishment of a logistics centre could be accommodated by the Mejillones Port Complex, whose Master Plan is already planning a large-scale expansion. The advantage of this option would be reducing negative urban impact (since it is not close to a city), the availability of space and the possibility of realising economies of scale. In addition, dredging would not be needed, whereas in the port of Antofagasta dredging is problematic, given the rocks at the bottom of the port basin. Finally, the port of Antofagasta could capture some of the additional port traffic if its layout is optimised and if activities that do not require quay access - currently housed in the EPA terminal - are moved to logistics centres at the edge of the city. 


\section{Aligning port and city planning}

Logistics is not an important part of city and regional strategies. Although the port master plans are aligned with urban and regional plans, and adhere to the various spatial regulations, e.g. with respect to coastal development and tsunami risks, the port does not appear prominently in city or regional plans. A shopping mall and public space has been developed in part of the area pertaining to the port of Antofagasta, which has increased the acceptability of port activity within the city. The port, however, does not seem to be considered by the national and city government as an economic asset of benefit to the city and its citizens.

This is a function of the way ports are governed in Chile, heavily influenced by the private sector and the central government, with little involvement at the regional or local level. As noted, many ports in Chile are private, either exclusively serving their owners, or open to use by other clients. A third category is the state-owned ports that encourage private sector activity, since private terminal operators are the only ones that invest in port infrastructure such as cranes. These are administered by public port authorities and owned by the state, which receives the port-related revenues (including from concessions to the private sector) and has a central vision on which ports to expand, based on the national interest. As a result, Chile's ports tend to develop independently of the cities in which they are located.

Close co-operation between ports, the government and economic actors would be needed to stimulate port diversification that could translate into economic diversification. This would require a common vision by economic actors on the economic development of the city, the region, the different ports and how they could service Antofagasta, as well as how the city and the region could facilitate port development and diversification. For such a joint vision, specific plans could be elaborated for port-related industries and urban logistics, building upon current ideas for logistics centres in Antofagasta. For example, co-operation could be intensified with the north of Argentina. To achieve closer co-operation, the traditional boundary between the nationally administered ports in Antofagasta and the city would need to be resolved by institutionalising interaction between the city administration and the management of the port.

Alignment of port and urban goals could be realised by urban or regional involvement in ports. Arguments for city or regional involvement in ports, rather than national government involvement, are that cities or regions would be more sensitive to regional value added creation of the port, and would have an incentive to invest in a port cluster and resolving collective action problems related to ports, whereas this is more complicated with a national public port authority, because of the risk of redistribution of funds (De Langen, 2004). There are several ways that cities can be involved in ports. The port can be an administrative branch of the city, the city can be a shareholder of the port, the city can be represented in the management board, the city mayor could appoint port directors or a harbour commission (as in the United States), and the city could own the port land. Many ports all over the world are controlled by city governments, including Rotterdam, Antwerp, Hamburg, Gothenburg, Los Angeles, Long Beach, Singapore and Hong Kong. There are countries where ports are controlled by regional governments, such as in Australia. Countries in which ports are controlled by national governments are France, South Africa and South Korea, however, many of these countries have institutional frameworks in which local governments are also somehow involved in port governance. For example, in France, local governments and other local actors are represented in port bodies. In Durban (South Africa), the signature of a Memorandum of Understanding (MOU) between Transnet and eThekwini municipality (the city of Durban) in 2003, which gave rise to what is now known as the Transnet and eThekwini Municipality Planning Initiative (TEMPI). The MOU establishes a 'Port-City Forum', whose purpose is to "develop a sustainable and pro-active planning and co-operative framework between the National Ports Authority (Port of Durban) and the eThekwini Municipality." The MOU intends for the forum to foster constructive engagement concerning matters that collectively affect the port and the city, and attempts to overcome previous information 
asymmetries by stressing the need to "identify and disclose planning initiatives and development projects of mutual interest between the Port and the City" (Rodrigue et al 2013).

In addition, some port authorities have started to take on a role as "community manager", which could facilitate the alignment of port goals with urban goals. This new role as community manager or cluster manager, as coined by De Langen (2004), has emerged to solve collective action problems related to ports. This has become more important considering the globalisation of port terminals and carriers, who lack affinity with cities and local communities and who have only limited ties with the ports so hardly any incentives to attract cargo in the port hinterlands, while being at the source of potential conflicts with societal stakeholders related to environmental protection, urban development, labour conditions and residents' interests. The port as community manager seeks to resolve these conflicting interests, e.g. by giving incentives to private operators for more sustainable behaviour. Ports have also taken up more entrepreneurial roles in resolving hinterland bottlenecks, training and education, port community systems, marketing, promotion and internationalisation.

\subsection{Improving the port-city interface}

\section{Tackling port-related congestion}

Various proposals outlined below have recently been floated to solve port-related congestion in the city. The most ambitious of these is the megaproject Nueva Circunvalación de Antofagasta (see No. 1 in Figure 2.7), as proposed by the Housing and Urban Development Agency (Servicios de Vivienda y Urbanismo, SERVIU), a deconcentrated agency of the Ministry of Housing and Urbanism (Ministerio de Vivienda y Urbanismo, MINVU) and funded by MINVU. In October 2012, SERVIU launched a public contract for the engineering design of the potential project (Mundo Maritimo, 2012), which might include an elevated bridge in the sea connecting the port with a new access to the highway and a 1305 -kilometre tunnel (see the connection labelled No. 2 in Figure 2.7), that is now the subject of ongoing feasibility studies by the Ministry of Public Works (Ministerio de Obras Publicas, MOP). The project is supposed to be completed by 2020, at a cost of CLP 50000 million (El Nortero, 2012). Another proposal under consideration is a tunnel in the south of the city, creating almost direct access from Route 28 to the port (see No. 3 in Figure 2.7).

It is doubtful whether some of these proposals, such as the port access via an elevated bridge to the Nueva Circunvalación, could justify the huge investment costs. Of course, they will have to be tested on their merits by proper analysis of the costs and benefits, including the obstruction of the urban waterfront. At first sight, the port-related congestion and relatively limited amount of port-related truck traffic do not seem to warrant these proposed investments. Similar measures, for example dedicated freight corridors, have been applied in other port-cities, but freight flows in these examples were much higher. In Valparaíso, a more or less dedicated freight route through a new tunnel to a distribution area was created, but the port of Valparaíso is not connected to railway lines, and the number of containers handled there is 10 times greater than in Antofagasta, which, when combined, results in approximately 25 times more port-related truck traffic than in Antofagasta. Another well-known dedicated freight corridor is the Alameda corridor, an underground railway link between the ports of Los Angeles and Long Beach and the main US railway network, but these ports have a combined container throughput around 150 times higher than Antofagasta's. Even in this case, the use of the corridor has been less than expected. The ports of Rotterdam and Amsterdam use a dedicated railway corridor, the Betuwe-route, but investment in this corridor has been heavily criticised as difficult to recover. Even in the largest ports, the use of dedicated freight corridors has not proved profitable, let alone for much smaller ports, such as Antofagasta. 


\section{Box 2. Alameda Corridor}

Alameda Corridor is a $32 \mathrm{~km}$ long freight rail cargo facility, connecting the transcontinental rail lines near downtown Los Angeles, California to the Ports of Long Beach and Los Angeles. The project is one of the largest public infrastructure works in the nation with a $\$ 2.4$ billion investment. The operation of the corridor commenced in 2002 . The centerpiece of the project is the Mid-Corridor Trench, which carries freight trains on triple track lines in an open trench that is $16 \mathrm{~km}$ long, $10 \mathrm{~m}$ deep and $15 \mathrm{~m}$ wide. The corridor was built by the Alameda Corridor Transportation Authority (ACTA), which is a joint powers authority formed by the cities and ports of Long Beach and Los Angeles in 1989. It is a public-private partnership project that involved various stakeholders, such as the two ports, Los Angeles County Metropolitan Transportation Authority (LACMTA), Southern California Association of Governments (SCAG), private railroad companies Union Pacific (UP) and Burlington Northern Santa Fe (BNSF), as well as the eight cities that the corridor passes. Its funding came from a unique mix of public and private sources, including a federal loan, grants from the LACMTA, user fees paid by the railway companies, investments from the ports, and revenue bonds. According to the ACTA, the goal of the Alameda Corridor is to consolidate train traffic and eliminate at-grade conflicts, as well as improving the air quality in the Southern California basin through reducing traffic congestion at rail crossings.

As a dedicated intermodal railway designed to improve the efficiency of transporting container cargo from the two ports to the national rail system, there are a number of benefits generated by the Alameda Corridor. It has resulted in more efficient rail movement, with a reduction of train transit time from over 2 hours to 45 minutes, as well as increased train reliability. Moreover, it eliminated conflicts at 200 at-grade rail crossings that reduce traffic delays and emissions from idling automobiles and trucks. As of April 2012, which marked its 10-year anniversary, ACTA estimated that more than 150,000 trains and moved more than 20 million TEUs (twenty-foot equivalent units) through the Alameda Corridor, resulting in more than 13,000 tons of total emission reductions from the consolidation of freight rail operation and the alleviation of traffic congestion at rail crossings in the Southland. The ACTA also provided training to about 1,300 area residents and created more than new 1,000 jobs during its construction process. Currently, the corridor has average daily traffic of 43 trains and cargo volume of 12,359 TEUs.

One key factor to the timely completion of the Alameda Corridor was the process to reach a consensus among various stakeholders from the public and private sectors. The ACTA was able to resolve conflicts of interests between stakeholders and created a publicly acceptable project by taking actions to accommodate their needs and concerns (Agarwal et al, 2004). The ACTA had negotiated settlements and signed memoranda of understanding (MOU) with each mid-corridor city, as well as to provide assistance in local economic development measures in order to secure their cooperation with project approval and construction. 


\section{Box 3. Betuwe line: dedicated freight rail link between Rotterdam and Germany}

The Betuweroute is a double track dedicated freight rail track towards Germany and into Europe. For the section from Rotterdam to the large shunting yard at Kijfhoek existing tracks were reconstructed, but three quarters of the line is new, from Kijfhoek to Zevenaar near the German border. The rail part in Germany is referred to as the Hollandstrecke. Together they formed project no. 5 of the Trans-European Transport Network program (TEN-T). The first discussions on the dedicated freight track go back to 1985. Work on the Dutch part of the track began in 1998. Before and during its construction the route generated a lot of controversy in political and community circles. In 2000 the Court of Audit stated that promoting river transport should have been considered as a realistic alternative. In 2004 the Centraal Planbureau concluded that the construction would never pay its way. Delayed by two years, the railway was finished mid 2007, at a cost of 4.7 billion euro, more than two times the original budget.

The Betuweroute is managed by Keyrail. The shareholders of Keyrail are Prorail $(50 \%$ - Prorail is the rail infrastructure manager in the Netherlands), Rotterdam Port Authority (35\%) and Amsterdam Port Authority (15\%). In 2010, rail traffic on the $120 \mathrm{~km}$ stretch between Kijfhoek and Zevenaar increased by almost $80 \%$ to 17,600 trains. The market share of the Betuweroute in comparison with the other border crossings for freight transport by rail to and from Germany has increased to more than $70 \%$ in 2010 compared to $45 \%$ in 2009 . The main motor behind this growth has been active tariff policy and the electrification - at the end of 2009 - of the Port Railway Line, the stretch between the Maasvlakte and the Kijfhoek shunting centre. As a result of this, many carriers switched from the 'mixed network' to the Betuweroute. In addition, the Port of Amsterdam got connected to the Betuweroute in March 2011 via a railway connection to the Betuweroute near Meteren/Geldermalsen. As such the Betuweroute is now serving both ports. Keyrail expects the number of trains on the Betuweroute to increase to 500 a week by the end of 2011 or a market share of about $75 \%$.

Figure 8. Proposed bridge and tunnel system for Antofagasta

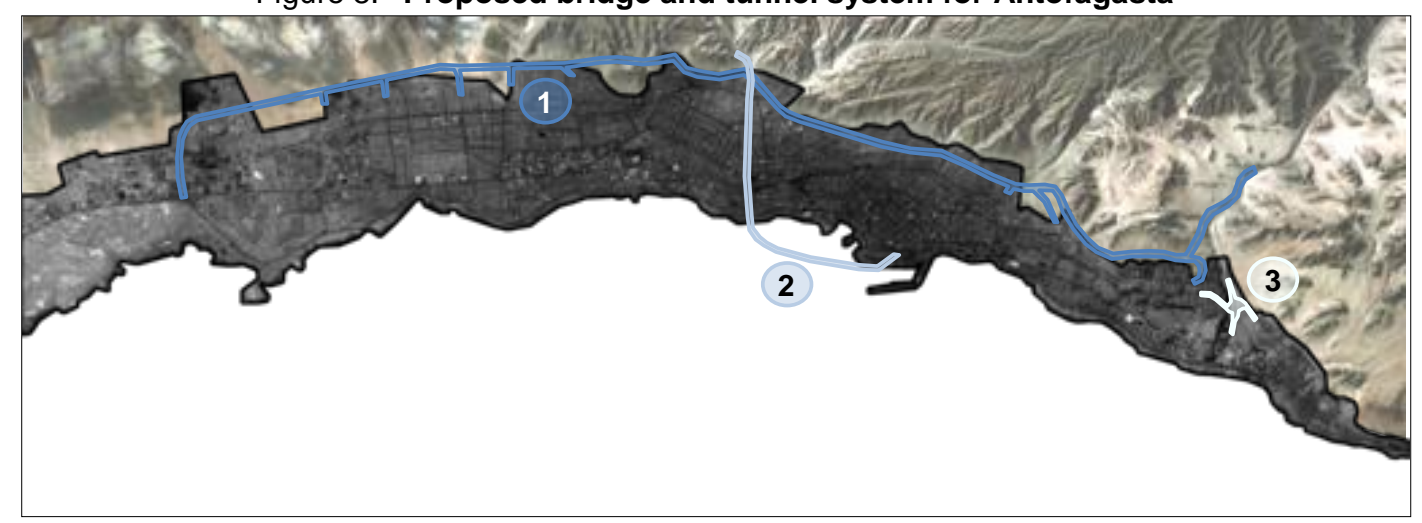

Source: based on figure provided by SEREMI MINVU.

To solve Antofagasta's congestion, serious consideration could be paid to developing a traffic management system with better co-ordinated timing of freight and passenger flows, including the possibility of a right of priority for public transport. Considering the regularity of the freight trains between the mines and the port of Antofagasta, their estimated arrival time at the different crossings with the urban street network can be modelled and brought in line with urban public transport networks. Similar systems have in various ports been applied for trucks, via terminal gate appointment systems. The Gate Entry Management (GEM)-system in the port of New Orleans and the WebAccess system of Georgia Ports Authority (GPA) are considered to be success stories. Both systems are web-based applications that allow dispatchers to schedule appointments and provide information for pre-clearance prior to truck arrival at the terminal; WebAccess allows customers 24 hours per day access to update data on container shipments. These applications have improved traffic flow, increased terminal throughput and improved productivity for trucking companies and terminal operators, with a reduction of truck turn-around times by $30 \%$ on average in the case of GPA (US EPA, 2006). 


\section{Conclusions for the port network}

The four ports in Antofagasta form an interlinked and resilient system, exclusively serving the mining sector. Port efficiency is one of the determinants of a competitive mining sector, but the port of Antofagasta is constrained by suboptimal layout and an underdeveloped public terminal. The exclusive port focus on mining has led to asymmetric trade flows (exports of mining products), with imports of food and consumer goods coming in via trucks from ports in central Chile, instead of via the ports of Antofagasta. As a result, Antofagasta has a relatively underdeveloped urban logistics sector. Not only do few benefits from the port spill over to citizens, they also face congestion related to truck traffic to and from the port, even if it is relatively limited in comparison with other ports all over the world. 


\section{BIBLIOGRAPHY}

Antofagasta PLC (2012), Annual Report and Financial Statements 2011, Santiago, Chile

Bown, R. et al. (2008), Sistema de Empresas SEP; Informe del Panel de Expertos Portuarios, Santiago, Chile

Cámera Marítima y Portuaria de Chile AG (2013), Statistics via website: http://www.camport.cl/estadisticas.php (last accessed 3 April 2013)

Cámera Marítima y Portuaria de Chile AG (2012), Generación de aguas abrigadas para el desarrollo de nuevos terminales portuarios en Chile; Propuestas para una política portuaria pública, Edicion al 26 de julio de 2012 de informe final, Santiago, Chile

De Langen, P. (2004), Governance in Seaport Clusters, Maritime Economics and Logistics, 6, 141-156

Empresa Portuaria Antofagasta (2008), Plan Maestro, Antofagasta, Chile

Hoffman, J. (2000), The potential for hub ports on the Pacific coast of South America, CEPAL Review 71, ECLAC, Santiago, Chile

IDB (2001), Mejillones Port Project, Environmental and Social Impact Report, September 2001, InterAmerican Development Bank

Marad (2001), By the Capes Around the World: A Summary of World Cabotage Practices, US Department of Transportation, Maritime Administration, Washington DC

Ministerio de Obras Públicas (2009), Infraestructura Portuaria y Costera Chile 2020, Santiago, Chile

Puerto Angamos (2013), Puerto Angamos, TGN, Overview, Presentation for OECD Delegation, February 2013, Mejillones, Chile

Puerto Angamos (2011), Memoria Puerto Angamos 2011, Mejillones, Chile

Rodrigue, J-P, Cooper, J., Merk, O. (forthcoming), “The Competitiveness of Global Port-Cities: The Case of Durban - South Africa", OECD Regional Development Working Papers, OECD Publishing

Rodríguez, J. (2005), El caso del Complejo Portuario Mejillones, in: Hellman, R., Araya, R. (eds.), Chile Litoral; Diálogo Científico Sobre los Ecosistemas Costeros, FLACSO-Chile, ACSS

US EPA (2006), A Glance at Clean Freight Strategies: Terminal Appointment Systems for Drayage, SmartWay Transport Partnership, US Environmental Protection Agency 